\title{
THE RETURN OF THE MYTH: ATHOL FUGARD AND THE CLASSICS
}

\author{
M McDonald (University of California, San Diego) ${ }^{1}$
}

Since the Greeks it has been difficult for any playwright writing in the West to avoid the influence of the Classics. The Classics have inspired many, not only with those fundamental themes that resonate in man's psyche, but with the myths that are part of our cultural heritage. ${ }^{2}$

The South African playwright Athol Fugard (born in 1932) lived through the rise and fall of Apartheid (1948-93), that oppressive regime that had one set of laws for people of color, and another for the whites in power. Without a flourishing theater tradition in South Africa, Fugard had to create one, so he adopted the ancient Greeks. ${ }^{3}$

1 This article is a reworked version of a lecture delivered during a research visit to the Department of Ancient Studies at the University of Stellenbosch.

2 These myths have been reworked in plays to express, among many things, even political protest (the Irish, for instance, have written over fifty plays based on the Classics in the twentieth century). See McDonald and Walton 2002:128-147 which includes an essay by Athol Fugard: 'Antigone in Africa', that also gives much useful background on the Serpent Players, and Sizwe Bansi. Athol Fugard directed my translation of Antigone in Ireland in 1999, where the accents (Belfast Catholic for Antigone vs. Ian Paisley's accent for Creon) made it apparent that the British occupation of Northern Ireland was being protested; this play was revived in 2004 to protest Bush (again made obvious by Creon's Southern accent). There are other protest plays based on the Classics, for instance, by the German playwright Bertolt Brecht (1898-1956) and the French writers Jean-Paul Sartre (1905-80) and Jean Anouilh (1910-87), to name just three who expressed their political concerns under the guise of the Classics.

3 In the four decades since Fugard's Orestes, many classics have come to be used as political weapons in Africa. See "Black Dionysus: Greek Tragedy from Africa” (Dioniso Nero: la tragedia greca dell'Africa), chapter in McDonald 1999a; and "Black Dionysus: Greek Tragedy from Africa” McDonald 2000:95-108. The Nigerian playwright Wole Soyinka wrote The Bacchae of Euripides: A Communion Rite that same year. In 1974, Barney Simon and Mannie Manim with the "Company" in Johannesburg staged Aristophanes' Lysistrata, and Bartho Smit wrote Bacchus in die Boland (Bacchus in the vineyards). In Smit's play, Bacchus comes to a wine estate and forces the white overseer to switch roles with his black employees, a storyline that appears to be roughly based on Aristophanes' Plutus. One can see the comic potential. The classic influence has continued. In 1975, Barney Simon, with war weary Angola in mind, directed Euripides' Trojan Women at Johannesburg's Market Theatre in 1977 in a version by Yvette Weyers. In 1983, the Junction Avenue Theatre Company, also in Johannesburg, produced an African version of Euripides' Bacchae, a play that also makes a political statement about masters and slaves. In 1990, Guy Butler published his Demea (based on Euripides' Medea), retelling it as the story of a white trekker who abandon his Tembu princess, and her subsequent vengeance. In 1994-96, Mark Fleischman and Jenny Reznek directed a postmodern Medea. Sophocles' Antigone stands for human rights and is popular at all times. Sabata wrote Giants: A South African Antigone and added music for a production at Cape Town's Nico Malan Theatre, July 10-21, 2001. Warrick Grier directed and designed that production, which conflates the story of Antigone with Hodova, an African legend, to show the abuse of power by absolute rulers in Africa such as Uganda's Idi Amin (1925-2003). Other African versions of the Classics include Efua Sutherlands Edufa (1962, after Alcestis); on the Oresteia: Tug Yourgrau's The Song of Jacob Zulu 1992; three Antigones: Femi Osofisan’s Tegonni 1994; Kamau Brathwaite’s Odale's Choice 1997; Sylvain Bemba's Black Wedding Candles for Blessed Antigone (1990, trans. Townsend Brewster) and Ola Rotimi's The Gods Are Not to Blame, a Nigerian version of 
Fugard's acquaintance with the classics began with his visits around 1945 when he was thirteen to a library in Port Elizabeth, and later when he was at university. He also enjoyed films on classical themes. Fugard has read H. D. F. Kitto's The Greeks (1951) at least five times. He was especially impressed by the statement in the first paragraph that claimed the Greeks "showed for the first time what the human mind was for." 4

One of Fugard's earliest plays, The Cell (1956) featured a Greek chorus. They wore masks and were unintelligible to the audience until the black janitor pointed out that if one cut holes in the masks for the mouths, then they might be heard. That same year, he had his first in-depth encounter with Greek theatre, while he served as dogsbody to the great Afrikaans actor, André Huguenet, as he performed in Cape Town in a celebrated production of Sophocles's Oedipus the King (1956), in which Fugard also had his first acting role as the shepherd. This story was the seed for Fugard's 2004, Exits and Entrances.

In 1963, a group of black people living in Port Elizabeth's black ghetto called New Brighton came one day to Fugard and asked him to direct them and give them plays. This meeting led to the formation of the Serpent Players, a name chosen because their first performances took place in an abandoned snake pit of a local museum. These black men and women, mostly laborers and domestic servants, were eager to be educated, and also to express themselves through plays that would deal with their own concerns (oppression, poverty, run-ins with the law, survival at ground zero and general issues of justice).

In 1965, the group decided to perform Sophocles' Antigone with Sipho Mguqulwa ("Sharkie") playing Haemon, but then Mguqulwa, in the course of the rehearsal period, was arrested on the usual trumped up charge of his papers not being in order, and for being a member of a subversive organization. He was sentenced to twenty years on Robben Island, where he created a "pocket version" of the play with another prisoner because he was so frustrated at having been "robbed of a chance" to perform in the Serpent Players' production. ${ }^{5}$ This experience on Robben Island was in turn the seed for Fugard's The Island (1973). Nelson Mandela, who would be elected the first president of South Africa after Apartheid in 1994, and who spent twenty-seven years in the same prison, played Creon in a performance of Antigone with other prisoners while he was in jail. ${ }^{6}$

Sophocles' Oedipus Tyrannus (ca. 426 BC), written in 1968 with the Nigerian civil war as a background, and John Pepper Clark's Song of a Goat 1964 (following one etymology for tragedy). See Wetmore 2002.

4 Kitto 1991.

$5 \quad$ See McDonald and Walton 2002:133. Several other classical plays were performed by the Serpent Players, including Shakespeare's Coriolanus, and also Euripides' Bacchae.

"When Antigone was chosen as the play [for a prison "concert" on Robben Island], I volunteered my services and was asked to play Creon ... Creon will not listen to Antigone, nor does he listen to anyone but his own inner demons. His inflexibility and blindness ill become a leader, for a leader must temper justice with mercy. It was Antigone who symbolized our struggle; she was, in her own way, a freedom fighter, for she defied the law on the grounds it was unjust” Mandela 1994:456. 
As Fugard's own plays developed, they began to have a classical structure. Beginning with Blood Knot in 1961, they often have just two or three characters, four at the most, and observe the classical unities of place, theme, and time. His plays rarely have intermissions and run about ninety minutes, as do most Greek tragedies. Like their classical Greek precedents, his plays do not depict violence on stage. They are also highly poetic and deal with universal human truths.

Fugard's Orestes (1971) was an experimental performance piece, strongly influenced by Grotowski, that Fugard composed on a classical theme. Orestes is a conflation of the ancient Greek myth of Orestes with the story of John Harris, a schoolteacher and Anti-Apartheid protester, who on July 24, 1964 left a suitcase filled with dynamite on a bench marked "For Whites Only" in the Johannesburg Railway Station. ${ }^{7}$ The bomb exploded; a seventy-seven-year-old woman (Edna Rhys, who was sitting on the bench with her granddaughter Glynnis) was killed and twenty-three people were injured.

The performance opens with the audience entering a room that has a single row of chairs around the walls. The three actors, an older woman, a younger woman, and a young man, are already sitting separately, looking like early arrivals. Only gradually do they establish themselves as the actors. A circular space in the center of the room containing a bench, a chair, and a suitcase is the acting area.

The young man, seated, plays with an empty matchbox, pushing it along his thigh to his knee until it falls over. He sits on the ground, and the girl joins him. They play together like children. They subtly suggest that the floor is a beach. The older woman observes them as a mother would.

The actors create, for the most part in silence, a series of changing, shifting images. The girl asks the older women how to spell "Orestes”, and using her finger, in response to what the older woman says, she traces the letters in the sand. The young man confronts his name and his identity: he is Orestes. It is clear now that the older woman is Clytemnestra, their mother, and that the younger woman must be Electra. This exchange contains the first spoken words in the piece. Then, the girl and boy make sand bombs and fight with them. They struggle to reach their mother by crossing a patch of sea, but by the time they do, she is about to give birth to Iphigenia, their sister.

In the myth, Clytemnestra's husband, Agamemnon, sacrifices Iphigenia to the gods so that the winds will blow and allow the Greek fleet to sail to Troy. In Fugard's piece, the chair Clytemnestra was sitting on becomes a symbol of Agamemnon; she attacks and dismembers it with her bare hands, then collapses amid its remnants. Her destruction of the chair is real, and a new one was used in each performance.

The boy and girl try to return to their games, but in watching their mother's act of violence, they have lost their innocence. They discover they are alone, and, to

The text referenced here is "Orestes: An Experiment in Theatre as described in a Letter to an American Friend” (American photographer Bruce Davidson) in Fugard 1990:117-130. It is a reprint of "Orestes Reconstructed: A Letter to an American Friend" Theatre Quarterly, 8.32 1979. It opened at Castlemarine Auditorium, Cape Town, March 21, 1971; Group: CAPAB Experimental Theatre Lab; Director: Athol Fugard; Cast: Yvonne Bryceland (Clytemnestra/old woman, Iris), Wilson Dunster (Orestes/John Harris), Val Donald (Electra/young woman); Settings: Johannesburg, mythological Greece. The line references will follow the quotations. 
quote Fugard: "The ugliest of all transformations takes place ... they become a threat to each other" (104). The girl confines the boy in a prison made of chairs from which he struggles to escape. When asked who and where he is, he answers: "Me. Male. White. South African. Here”. And so Orestes becomes Harris. The girl gives him a suitcase and creates the ticking sound of the bomb inside by flicking her nail against the matchbox.

The older woman moves from the shattered chair to a bench and the young woman joins her there, as does the young man. He opens the suitcase and fashions the newspapers inside into bombs. They are torn up to show the explosion in very slow motion. When the newspaper bombs go off:

[Iris, the name the actors gave to the old woman] ... pushes herself to the edge of the bench and drops to the floor. She experiences herself as being utterly alone. The petrol has burnt away the soles of her feet. She wants to walk but cannot. She wants to cry but all that comes out are small sounds of disgust as she grabs her ankles and, using her heels and her arse, drags herself away across the floor of a station concourse so vast and empty it looks like the floor of a palace. (125-26)

After a few moments, each of the actors reads a short text to the audience. Orestes/Harris, quoting from Harris' trial testimony, speaks of his ecstatic happiness as he waited for the bomb to go off, and adds: "I knew that what I was doing was right. Later I heard that people had been hurt, but this did not make sense because I had known that people were not going to be hurt” (126).

In his notebooks of September 1970, Fugard discussed the uses he made of the Greeks in developing this reworking of Orestes' dilemma - to use or not to use violence - a choice that many a South African political activist had to make. Fugard said he went to Aeschylus for Clytemnestra and to Euripides for Orestes and Electra.

In the Oresteia, Aeschylus deals with Clytemnestra's rage. Aeschylus had a keen sense of divine justice and retribution, whereas Euripides concentrated on manmade crimes and their aftermath. Euripides' Electra and Orestes focus on the vengeance that people took rather than on the solution that Aeschylus devised in his Eumenides (the last play in the Oresteia). Aeschylus put an end to the violence in the Eumenides by the establishment of a law court, but Euripides suggests that violence will go on and on in a tragic cycle - a warning particularly appropriate to South Africa in 1971.

To awaken the feeling of loss in Yvonne Bryceland, the actress playing Clytemnestra, Fugard told her: "Imagine there was somebody in your life you called to, you said their name every day until suddenly, one day, she didn't answer”. Bryceland said of this and other devices that Fugard used in his directing:

He will find your point of pain and remind you about it. That moment was terrible for me; I can hardly think about it now. We managed to do the play night after night because Athol had been able to touch wells in us that could be repeated in the same pain - without any technical tricks or things like that. Clytemnestra went mad for this child that would never answer her again. ${ }^{8}$ 
As a result of Fugard's directing, Clytemnestra first breaks Iphigenia's name down into animal noises, grunts, and groans (to convey the pain and struggle of giving birth) and then reassembles the syllables as Iphigenia is born. Then later, in exploring a mother's sense of loss, Fugard has Clytemnestra call Iphigenia repeatedly, with growing desperation and anguish, until finally and irrevocably, there is no answer. In both instances, naming signifies existence, identity, and life. That human being will be the one who is named Iphigenia, and Agamemnon will destroy her and she will be absorbed into the silence of death. After the sacrifice Clytemnestra

first called, as a mother would to a child in the next room ... silence

then called a little louder as if she were playing in the garden ...silence

louder still, as if she was quite far away ... silence

and still louder, shouted, screamed, whispered ... silence

then broken down again into its elementary syllables to provide a vocabulary for grief ... silence. (123)

The cycle is complete: her daughter has reentered the universe through the sounds of grief and finally silence, from the named to the inarticulate.

Because Clytemnestra laments the loss of her child, a "sacrifice" she regards as murder, she will murder in turn. At one point, it seemed to Fugard that Bryceland was not quite clear enough about Agamemnon's character. To make a point of Agamemnon's arrogance, Fugard spontaneously arranged all the tables and chairs in the rehearsal room in the shape of Agamemnon's ship as it was sailing back to Argos from Troy carrying Cassandra, the daughter of the Trojan King Priam, as a trophy of war. He then stripped off all his clothes and strutted up and down on the tables pounding his chest and bellowing, "I am Agamemnon the King! I am returning from Troy with Cassandra my prize!” From Clytemnestra's viewpoint, now Agamemnon had not only killed their daughter, he had also brought home a concubine. Fugard said he saw an "evil glint" come into Bryceland's eyes, and he knew that she had gotten the point. From then on, she knew exactly whom she was killing, and she did it literally with a vengeance.

Fugard worked intensively with Bryceland on the part where Clytemnestra destroys the chair that is Agamemnon. Fugard told her to get to know the chair: "Love it. And as you love it, look for its flaw, its imperfection, its one fatal weakness”. Many an abused wife has fought back this way.

Each night, Bryceland followed Fugard's direction to find the weak parts of the chair and smash it to bits. Then, drained by her own violence, she would collapse to the floor. As Fugard described it:

Every performance ... Clytemnestra destroyed one unique, irreplaceable chair called Agamemnon. It was an awesome and chilling spectacle. You cannot destroy without being destroyed. As she went through the experience $\mathrm{Y}$ [Bryceland] wrecked her soul”. (123) 
This was an experimental performance piece, but it also was held together by a plot, and the interlinking theme of revenge: Clytemnestra on her husband, and Harris on Apartheid. Both lead to added violence that simply keeps the cycle going. The same actor who played Orestes also played Harris, so the old woman Harris killed on the park bench, was paralleled by Orestes killing Clytemnestra. Harris was attacking his motherland, which provides an additional parallel.

The plot was emotionally driven rather than structured in a chronological or logically linear way. Fugard juxtaposed the mythical events of the Orestes myth with the historical events of the bombing in such a way that each offered commentary on the other.

The last lines that each character delivers, express some of the most personal imagery of the characters: first, Harris' justification of himself (he sincerely thought no one would be harmed); second, Electra's speaking of vomit, love turning to hate, in other words, the way she felt towards her own mother, as possibly all women with the Electra complex do, (this is an attribute that also applies to Clytemnestra since her love turned to hate); and third, Clytemnestra wishing she could communicate her reasons for what she did, and make someone else understand (both she and Electra quote passages from R. D. Laing that provide insights into their characters). ${ }^{9}$ Fugard said that with these quotations Clytemnestra was trying to communicate how hollow she felt after the murder she committed, or as he said: "honeycombed with space". Of course, the symbolism is more complex than this. In The Divided Self (1960), Laing was speaking about schizophrenia, a pathology that could also be ascribed to South Africa under Apartheid, with its systematic division of the country. Laing's later book Sanity, Madness and the Family: Families of Schizophrenics (1964) demonstrates how madness is a shared family disease, thus underlining the parallel between members of the ancient house of Atreus and South Africa, exactly as Fugard draws it in this play. ${ }^{10}$

Clytemnestra, the mother figure, is an earth mother, who becomes a raging animal when her offspring is taken from her. The children play games and try to understand what is expected of them in response to what they see. Electra is an instigator, and Orestes becomes caught up in a violence much more intense than he ever expected. Both are perpetrators and both are victims. So is their mother. It is a paradigm for society in general where there are rarely pure criminals or pure victims.

Harris' story is an apt parallel to Orestes' in that both show violence in the pursuit of a cause - but did Orestes really need to kill his mother? Some revolutionary causes seem just: Apartheid had to be opposed. However, just as the Greeks needed to establish a law court to end blood vendettas as they did in Aeschylus' Oresteia, so did John Harris need some more rational way to express his anger. South Africans themselves established their own staging of Aeschylus'

\footnotetext{
9 Just as the Oedipal complex shows a son with a homicidal urge towards his father as a way of defining himself by displacing his father, the Electra complex shows the same phenomenon of a daughter needing to supplant her mother as a requisite for her own existence. These urges obviously need to be sublimated.

10 These last points were suggested by Philip Howard in a seminar I gave at the University of California, San Diego, in 2005 on ancient classical drama and plays by Athol Fugard.
} 
Eumenides with their Truth and Reconciliation trials (1995-98), to avoid the violence that very well could have resulted after Apartheid was abolished. Orestes vividly depicts both the brutality of violence and the lesson that brutality brutalizes something we see again and again in Euripides' plays, from Medea, to Hecuba, Orestes, and Bacchae.

In his notebooks, Fugard said: "Harris stood in relation to his society as Orestes did to Clytemnestra. An intolerable burden of guilt for the crimes committed — the act of violence an attempt to escape the burden of guilt" (188) ${ }^{11}$ He added: "Among many things we wanted in this way to say to our audience of white South Africans: 'You could have been the person beside whom a young man left a large brown suitcase"” (189). Fugard in this play has opened up the political and psychological realities of the Greek original.

Another Fugard play that resorts to the Classics to protest Apartheid is The Island (1973). ${ }^{12}$ It takes place in four scenes, opening with a lengthy mimed sequence in which John and Winston, two cell mates in prison on Robben Island, carry out one of the totally pointless and exhausting tasks designed by warders to break the spirit of political prisoners. Winston has been sentenced to prison for life because he burned his passbook in front of a police station. John has been imprisoned for belonging to a banned organization.

The story traces the relationship of these two men. Winston is the active rebel, and John, the intellectual, is trying to persuade him to play Antigone in a condensed two-character version of Sophocles' play. It is to be a prison "concert" for their fellow prisoners and the guards. However, Winston rebels at playing Antigone. He doesn't want the other prisoners to laugh at him for being dressed as a woman, wearing a mop for a wig, false "titties," and a necklace made of salvaged nails. He protests, "I'm a man, not a bloody woman ... Shit man, you want me to go out there tomorrow night and make a bloody fool of myself?” (208).

John finally convinces him to cooperate by putting the dress on himself and saying, “... behind all this rubbish is me, and you know it's me. You think those bastards out there won't know it's you? Yes, they'll laugh. But who cares about that as long as they laugh in the beginning and listen at the end. That's all we want them to do ... listen at the end!” (210).

Then John is taken to the office of the head warden and told that his appeal against his sentence has been granted. His ten-year term has been reduced to three years. In three months, he will be free. But Winston is now facing a bleak future without the friend whose imagination has helped to keep him sane.

In the final scene, as the two present their version of Antigone, Antigone/Winston tells the legendary king of Thebes, Creon, and the audience:

This and the following references come from Fugard 1984.

Page numbers in this section will refer to Walder 1993. For work done on the subject of Greek myth being used in African drama see McDonald 1999a, with an expanded introduction, epilogue and additional chapter, "Dioniso Nero: la tragedia greca dell'Africa" (Black Dionysus: Greek Tragedy in Africa); McDonald 1999b:145-167; 2000:95-108; Wetmore 2001; and McDonald and Walton 2002 (see note 2). 
You are only a man, Creon. Even as there are laws made by men, so too there are others that come from God. He watches my soul for a transgression even as your spies hide in the bush at night to see who is transgressing your laws. Guilty against God I will not be for any man on this earth...But if I had let my mother's son, a Son of the Land, lie there as food for the carrion fly, Hodoshe, my soul would never have known peace. (226)

"A Son of the Land" (Nyana wa Sizwe) is Winston's battle cry that articulates his identity. At the end of the "concert," John and Winston then take off their costumes and "strike" the set. They are again put in handcuffs and ankle chains and begin running in tandem as the siren wails.

When Kani and Ntshona asked Fugard about a play for them, he thought they should have a play about the one place no one in South Africa talked about for fear of political reprisals: Robben Island. Fugard gave Kani and Ntshona his sketches and outline for The Island, in fact, a nearly completed play.

For The Island, Fugard turned to Sophocles, the playwright of heroism whose Antigone, the first conscientious objector, is the first female character in drama to be a hero in the full sense of the word. John and Winston use the literature imported by their colonial "masters" as a weapon for counterattack. Ironically, this literature - in this case, Greek tragedy — has subverted the colonial masters' intentions by teaching them the meaning of human rights rather than playing the pacifying and "civilizing" role the colonizers intended.

Fugard had already drawn from Aeschylus and Euripides in Orestes. The three playwrights had different world views. Aeschylus' plays show that he believed in a world governed by the gods and that they had a hand in controlling men's affairs, along with fate. Euripides, by contrast, centered his plays on people, and saw their downfalls and triumphs as consequences of their own decisions and actions. And finally, although Sophocles did believe in the gods, he also believed that humans could take their destiny in their own hands and, if they could not shape it directly, at least they could respond to their circumstances with heroism.

The structure of The Island itself resembles Greek tragedy in that scenes about actual conditions in the prison alternate with scenes from Antigone. The former could be considered as epeisodeia, or acts in a Greek play, and the latter as stasima, the choruses. As a chorus comments on the action, so does Antigone give additional insight into John and Winston's actual predicament. Antigone finally becomes part of the action itself and the chorus merges with the act because the performance itself is an act of protest.

Apartheid demanded that blacks assume roles that were defined by a passbook. By choosing to enact Antigone, John and Winston use theatre itself as a weapon against those who think they are directing the theatre of life in South Africa. John and Winston transform the theatre of acquiescence into a theatre of protest. Like Nelson Mandela, they are in prison for expressing their views that blacks should be treated as equals with whites, a dangerous opinion under Apartheid.

Their version differs in obvious ways from Sophocles' original, but that is John's and Winston's intent, because Antigone serves mainly as a metaphor for the conflict between individual conscience and the laws of the state (the reason they are 
in prison). They also firmly believe that they are the heroes and obviously in the right, whereas Apartheid is an evil Creon. However, Antigone in Sophocles' play seems as unwilling to work out a solution as Creon is, so both sides are at fault. In The Island, technically there is no chorus, nor do the gods underlie the action in the same way they did in the Sophoclean original, including an appearance of their prophet, Tiresias. Creon in The Island neither achieves tragic insight nor offers the persuasive arguments that he did in Sophocles, arguments that gained Hegel's admiration since he saw good in both Antigone and Creon. The villain in The Island is Apartheid, and like Zeus in Aeschylus' Prometheus Bound, the system that has victimized these innocent men is always present, yet never seen, and also clearly in the wrong. However, this absence of ambiguity that usually defines Greek tragedy - The Island's clear articulation of right on one side and wrong on the other - does not interfere with the tragic element or with the directness of the drama in affecting the audience's emotions. ${ }^{13}$ As the Soviet dictator Stalin (1879-1953) said: "The death of one human being is tragic, of ten thousand, a statistic". Winston's tragedy is one that the audience feels. What this play lacks in classical ambiguity it gains from the human drama and modern political commentary.

John has been imprisoned because he was a member of a banned organization. Several members of Serpent Players were also imprisoned on trumped up charges, but in fact because Serpent Players itself was suspected of being a political organization. Theatre has always the potential of being dangerous.

As in most regimes that seek to dehumanize and subdue "others," the prisoners in The Island are subjected to humiliation, including body searches, being forced to urinate in humiliating circumstances (for instance, on the long bus ride to the prison when they were not allowed stops to relieve themselves), and being treated as if they were animals.

However, John and Winston know their own value. No matter how the guards try to obliterate their identity and humiliate them, they retain the essential knowledge that they are human beings. Their performing Antigone proves it, because their highly abbreviated version makes it clear that Creon represents the oppressive power of Apartheid, and Antigone represents human rights. Representing Antigone's moral victory is the prisoners' passionate way of fighting back.

The original South African audience outside Robben Island left the theatre, and this play about prisoners, to return to their own prison of Apartheid. When John and Winston perform in front of their guards, they also indict them.

13 See Maclennan, “The Palimpsest: Some Observations on Fugard's Plays” in the volume just cited, 217-23. He claims that in Fugard's plays, "what is most real about man is his sense of civilized values, and that man could not survive unless each child and each helpless victim of life re-created civilization within himself and with at least one other person,” p. 223. For the background of this play, along with its companion piece, Sizwe Bansi Is Dead (1972), see Walder 1993: 409-22. Vandenbroucke 1985:131 claims that "Bansi knows his assumed identity will one day be discovered" and that The Island "is more hopeful and optimistic than any of Fugard's others”. I think the opposite is the case, which Fugard verifies. Bansi's identity will not necessarily be discovered, whereas Winston, like Antigone, is abandoned. There is much less hope in The Island than in Sizwe Bansi. But it is interesting how plays can be Rorschach tests for readers, and great plays, even more so. 
The self-conscious metatheatrical devices, the minimal set, and the actors' addresses to the audience - who become the prisoners and guards during John's and Winston's performance - reduce theatre to its bare bones and involve the audience in the new creation. It becomes all the more powerful by dint of its basis on myths that have entered the human psyche. As Freud noted with the myth of Oedipus, there are certain myths that take up residence in the human mind and soul because they reflect primitive urges. Antigone's struggle is one such myth and asks the question: when should the individual oppose authority?

The Island is itself an existential parable, beginning as it does with repetitive actions as absurd as those described by Albert Camus in The Myth of Sisyphus (1955). Man is responsible himself for making choices, however restricted, in this absurd and consequently unreliable universe.

In Antigone's final speech, Winston addresses the audience directly:

Brothers and Sisters of the Land! I go now on my last journey. I must leave the light of day forever, for the Island, strange and cold, to be lost between life and death. So, to my grave, my everlasting prison, condemned alive to solitary death.

Tearing off his wig and confronting the audience as Winston, not Antigone.

Gods of our Fathers! My Land! My Home!

Time waits no longer. I go now to my living death, because I honoured those things to which honour belongs. (227)

The last sentence of his speech is a literal, albeit abbreviated, translation of Antigone's final words in Sophocles' play. Both express the struggle of personal conscience against a regime they see as wrong in the laws it has enacted. We are left with an image of human triumph. In this play, human oppression is overcome by the greatness of the human spirit. Here we see Greek tragedy used at its best as catharsis, hope, and revelation in this new psychologically true version by Fugard.

Dimetos (1975) is very loosely based on classical themes. ${ }^{14}$ It tells of an older man (Dimetos), an engineer, betraying his ward (Lydia, his niece) in a way that causes her to commit suicide. He goes mad, but redeems himself by creating, and learning to give and take, namely developing compassion. Dimetos was inspired by a character about whom Fugard read in the notebooks of Camus, who

indirectly caused the suicide of his orphaned niece: Dimetos has a guilty love for his niece, who hanged herself. One day, the little waves carried on to the fine sand of the beach the body of a marvelously beautiful young woman. Seeing her, Dimetos fell on his knees, stricken with love. But he was forced to

$14 \quad$ Line references are based on Dimetos, and Two Early Plays 1977. 
watch the decay of this magnificent body, and went mad. This was his niece's vengeance, and the symbol of a condition we must try to define. ${ }^{15}$

In his unpublished thesis, Michael Mitchell (who produced Dimetos in Germany in 1991) quotes the following, which he translated from German:

Dimoites was the brother of Troizen, whose daughter Enopis he married. Enopis hanged herself through fear and shame because of her forbidden loveaffair with her brother, after Dimoites, who told her father about her crime, had first cursed her. Not long afterwards he came upon a female corpse of great beauty washed up by the waves, and seized by love he abused it. When the body started to decay and he had raised a high burial mound for it, he stabbed himself because his passion would not abate. ${ }^{16}$

Dimetos is the most abstract of Fugard's plays. At its core is a universal myth: the creator who suffers at the edge of society and is punished for his transgressions. Many critics have noted its links with several ancient Greek tragedies. ${ }^{17}$

For example, there are parallels with the incestuous Phaedra, who fell in love with her husband Theseus' son Hippolytus (Euripides' Hippolytus, 428 BC). Fugard's Lydia hangs herself, like Phaedra, out of shame and disillusionment. Sophia is like the nurse in Hippolytus, an advisor to her ward, but she betrays Lydia out of jealousy. Sophia, instead of bringing the "lovers" together (like the nurse in Hippolytus), tries to separate them.

As mentioned earlier, Dimetos' very name refers to a classical myth, and the play also mentions Daedalus and Prometheus. Daedalus, the master craftsman who created the labyrinth to imprison the Minotaur, is analogous to Dimetos the engineer. However, Prometheus, who gave humanity fire and taught men the arts, mathematics, astrology, medicine, and other skills, is the patron of the artist, whether the transformed Dimetos or Fugard himself. Fugard has said that he thinks the "fire" Prometheus gave mankind was imagination, without which there can be no creation.

In another classical echo, that of Demosthenes filling his mouth with pebbles and practising his oratory at the seashore, Dimetos shouts his name to the sea and says: "The waves will break it up and tomorrow, after high tide, I'll pick up the pieces” (39).

Also, the second act begins with Dimetos invoking the elements of water, earth, fire, air: "Sea. Sand. Sun. Sky. Elemental” (38). He then addresses the evidence scientifically: "The footprints leading across the wet sand to this moment, suggest a purpose" (38). He has translated the elements into what he sees in the African landscape. Such an elemental beginning was anticipated by the Greek Pre-Socratics,

15 Albert Camus 1996:136. The myth is in Erotica Pathemata, "Unhappy Love-Stories" by Parthenius, "a minor Greek author of the late Hellenistic period, active in the first century BC," Whitaker 1981:45-59, and specifically note 3 on p. 58.

16 Roscher 1884-1886:cols. 1020-21, quoted in a chapter from his unpublished thesis, Hidden Mutualities: Faustian Themes in the Postcolonial, footnote 12, p. 171.

17 See Vandenbroucke 1985:209-211, Appendix B: “Literary Ancestors of Dimetos". Vandenbroucke also speaks about Faust, and goes into western literature in general. 
who each chose one or several of these elements to explain the universe: Thales (water), Heraclitus (fire), Anaximenes (air), and Empedocles (earth, air, fire, and water).

Dimetos' madness towards the end of the play is as much a rite of passage as the descents into hell in the Odyssey (Book 11) and the Aeneid (Book 6). In both cases the epic heroes gain knowledge, and after making a journey "to hell," the creator attains a clearer vision. Although Dimetos goes through a phase of madness, it is only a transition - a necessary prelude to the rebirth of his creativity, for as Plato tells us in his Phaedrus, madness is necessary for creation.

The story of Dimetos is a myth about a creator who is trapped in a loveless technological world and who has become as cold and unsympathetic as technology itself. He must relearn the value of the human heart before he can learn to create again. In the end, it is through stories that Dimetos will escape what is called the labyrinth of time: "Man is the only animal to be trapped by time. That's the real labyrinth ...” (23). Art and imagination are what put wings on the creator who would escape the cage of the labyrinth: he can fly like Icarus, for whom Daedalus fashioned wings. An artist's work defies time.

The Abbess (2000) is a play that has not yet been performed.$^{18}$ It is based on Hildegard of Bingen (1098-1179), the famed nun, composer, religious authority and author who became known as the "Sybil of the Rhine". She faces a problem like Antigone's in that it involves the proper burial of a body, this time in the convent cemetery: although she was ordered to disinter the body of a man whom she was told was excommunicated by the Prelates of Mainz, Hildegard refuses to do this because she knows otherwise. As punishment her convent was put under interdict. However, she sticks by her principles and what she knows to be right, until finally the Archbishop of Mainz, who has been away at Rome, restores her convent's privileges. Her visions lead her through a dark night of the soul, but she emerges stronger than ever in her faith, besides having won a political victory.

Fugard's play evolved over many years. In 1994, he picked up a CD of Hildegard's music and learned about her heroic confrontation with the Prelates of Mainz. Given his lifelong interest in stories of people "on the edge" who confront crises, this piqued his curiosity, and over the next six years, he read everything he could find written by and about Hildegard. As he learned more, his admiration for her grew, and he also began to see parallels between Hildegard's story and that of one of his favorite characters, Antigone - the woman par excellence who followed her conscience rather than bow to abusive authority.

Antigone - the first heroine in Western literature to stand up to unjust laws as a "civil disobedient" - insisted on obeying "the unwritten law of the gods" and burying her ostracized brother against King Creon's decree, for which she was locked up in a cave to die. The parallels with Hildegard, who followed her conscience and buried Albrecht against the Church authorities' dictates, were obvious. At a metaphorical level, the interdict placed on her entire convent locked her and her community in a "cave of silence”. Unlike Antigone, however, Hildegard ultimately

Quotations are from the unpublished manuscript. The play is dedicated to me. 
prevailed, and her victory was won during her lifetime. However, both women have acquired immortal fame by their courageous actions.

Fugard has used Sophocles' Antigone in various ways over the years and in addition to that has directed my translation of Antigone in Cork (1999) and Listowel, Ireland, with an international and multiracial cast. ${ }^{19}$ This story resonated with as much significance for the Irish, who had suffered under British occupation, as it had for the South Africans under the weight of Apartheid.

The Abbess, which begins in silence and stealth, ends with a glorious hymn to God. The beginning resembles the opening of Sophocles' Antigone, when Antigone decides to obey the laws of the gods and to defy her uncle Creon's orders. Hildegard follows the unwritten laws of God as these are spoken to her directly in her visions. As they built their own convent in Rupertsberg, near Bingen, Hildegard said:

We lifted our voices in praise of the Lord, and laughed at our bleeding and blistered hands as we broke rocks to build these walls. It is not mortar that holds them together now ... it is song.

Just as in ancient Greek myth, Amphion played and the stones moved in response to his songs to build the walls of Thebes, so too the sisters in Hildegard's community could do backbreaking work with the help of song.

Like Sappho, Hildegard introduced her community to the world of art specifically, music - as well as to the world of the spirit. She enlisted new members from the upper classes, and they came with their servants and their lavish dresses, even wearing them for certain celebrations and performances. Hildegard was a strong woman who appreciated wealth and splendor.

Hildegard's victory, like Antigone's, shows the triumph of conscience. Similarly, the new South Africa, with its fine constitution that advocates equality and justice for everyone, prevailed over the misguided authority of Apartheid.

Sentencing Hildegard to silence during the interdict was like destroying her soul. Just as song inspired and held the nuns together as they were building the convent, the silence imposed on them leads to the community's spiritual disintegration. The glorious singing at the beginning and end of the play is in frightening contrast to the whispering that becomes a constant undertone after the interdiction is imposed.

The enforced whispering (which pervades the action as indicated in the stage directions, an ominous subtext) is also symbolic of all women who are oppressed by men, whether by legislation or emotional blackmail. Like the Furies at the beginning of Aeschylus' Eumenides, powerful women like Hildegard are antagonized by, rather than integrated into, the social structure as they should be. Both Aeschylus and Fugard achieve that integration in the course of their respective plays.

Music is one of the most powerful ways an artist or creator can speak with God. It has always been vital for Fugard and his work. Hildegard's final command to her nuns is: "Now sing!” Their joyous song ends the play. This Antigone did not die Sophocles’ Antigone, trans. Marianne McDonald 2000; rpt., 2004. 
in a cave, but when she followed the 'unwritten laws of the gods,' her God answered her prayers, and she thanks him in song.

Sorrows and Rejoicings (2001) tells the story of a South African man (Dawid Olivier) who is an exile from his beloved country, South Africa, just as Ovid was. ${ }^{20}$ Two women, one coloured and one white, forge an alliance at his funeral, just as South Africa in 1994 chose compassionate understanding over hatred. There are memories in which Dawid appears - five, in fact, just like the acts of a Greek play.

Fugard has said that he wanted to write something about the many South African artists who became active in the Anti-Apartheid movement, went into exile, and often found their creativity dried up because they were away from their homeland. Some committed suicide, and others never wrote another creative word. One such exile was C. J. Driver (1941-), who emigrated to England. Both he and Fugard identified with the Tang Dynasty poet Li Po (701-762), the author of Poems of Exile. Like the Roman poet Ovid (43 BC-AD 17), exiled in $8 \mathrm{AD}$ by the Emperor Augustus, Li Po alienated the ruler of his country and was forced into exile. In fact, Fugard has Dawid quote two of Ovid's most moving lines about exile: ${ }^{21}$

My message will travel to all the people,

All over the world my charge will be heard

From where the sun rises to where the sun sets

Both East and West will witness my word.

Over the earth and across vast seas

Shall the sound of my outcry be great.

Not only the present will know your crime,

Indicted forever will be your fate. [Ovid, Tristia 4. 9 (23-24)]

He uses these lines to convey his dream to Marta: "All over the world my charge will be heard".

My talent, which at its best was only slight,

Has rusted now and lost its sheen.

A fertile field without the plough,

Grows only grass and thorns and spleen.

I fear I'm not the man I was,

And I was little even then.

Long suffering dulls the sharpest wit:

There's no edge left to tongue or pen. [Ovid, Tristia 5.12(34)]

These last lines are used to express his despair to Allison, during what he regarded as their London exile. This play expresses sorrow for the abuses of Apartheid and rejoicings for the new South Africa; it also laments the sufferings of the exile, anytime, anyplace.

Fugard uses the Classics again in Exits and Entrances (2004), a play that is based on two meetings between the Playwright (Athol Fugard, though he is never

$\begin{array}{ll}20 & \text { Line references are to Sorrows and Rejoicings } 2002 . \\ 21 & \text { Fugard used my translations. }\end{array}$ 
referred to as such) and the great Afrikaans actor André Huguenet (1906-1961). ${ }^{22}$ The first meeting takes place in 1956, when André is fifty and the Playwright is twentyfour. In the second meeting, five years later, André is about to end his life (probably by suicide), whereas Fugard is busy finishing The Blood Knot (1961), his first commercial success and winner of critical acclaim at home and abroad.

As the play begins, the Playwright reads a newspaper article announcing the death of André, then begins speaking directly to the audience as he reminisces about André's production of Sophocles' Oedipus the King at Cape Town's Labia Theatre five years previously. Now André tells him that Oedipus had bankrupted him, and he could not find work as an actor because his style was considered outdated. He ended up as a manager, ticket-taker, and usher at a shabby movie theatre, where he lived in dread that someone who had seen him on stage would recognize him and see how far he had fallen. He feels he is desperate to stand in the light of day as his true self: "Wear my curse - The Dopper Moffie ["village queer"] — as a badge of honour and not one of disgrace” (42). Being both a homosexual in South Africa, and a failure at what he could do best, had destroyed him. He still gives a blessing to the young author: "Fan the flames of your purpose. Make it burn as big and bright as you can" (43). The next thing the author would hear, is that André was dead. The final words in the author's notebook reflect on "the duplicity, the paradox that runs so richly through all this life. And then sleep” (47).

In the course of Exits and Entrances, Fugard has André deliver many passages from plays in which he appeared. These are particularly moving because they describe the older actor at various points in his life. For example, the Playwright's opening reminiscence is a graphic description of André's agonized cry when Oedipus realizes that he has murdered his father and married his mother, and is both father and brother to his own children:

André, as Oedipus, standing at the top of the steps in front of the doors of his Theban palace, became very still, and we ordinary mortals held our breaths and waited. In those terribly silent seconds it seemed as if the whole world was waiting, and at the point when you thought you could no longer endure it and would have to scream, at that precise moment, not a second too soon or too late, André opened his mouth and out of it came the most awful cry that any member of that audience had ever heard. It sounded as if he had somehow reached down deep into himself and was dragging his genitals up through his body and throat and hanging them out of his mouth for all of us to spit on and curse. And that wasn't just one memorable performance! Oh no. André knew it was the moment of the play, so he hit that mark with uncanny accuracy virtually every night. (2-3)

André's roles were delivered in blood, and he tells the Playwright that as an actor he "lusts after those final moments of [Oedipus'] unspeakable agony and terrible

22 The text used is Fugard, Exits and Entrances 2005. For the quotations from Sophocles, Fugard used my translation of Oedipus Tyrannus, produced in Fall 2003 at the Sixth at Penn Theatre, San Diego, and directed by George Ye. 
torment. I've even come to love the taste of that stage-blood dripping from my face..." (17). Acting was his own lifeblood, and his roles were his life.

Towards the end, André met with rejection, but it did not deter him from devoting himself entirely to his ideals, which achieved recognition throughout the world earlier in his career. Like Oedipus, he carried on until he went bankrupt and could carry on no longer. He was highly decorated by his countrymen but did not achieve commercial success.

Oedipal themes recur throughout the play. For example, Huguenet, who, by giving Fugard his first formal acting role as the shepherd in Oedipus, became Fugard's "dramatic father," so both of Fugard's fathers died the same year. The Playwright's ambivalent relationship with his dying father also emerges, though in much less polarized terms than in "Master Harold" ... and the boys (1982) and The Captain's Tiger (1997):

PLAYWRIGHT. ... I suppose I'm also waiting for my own father to die?

ANDRÉ. That sounds a bit Oedipal, dear boy.

André is imperious, witty, if not catty, and idealistic, although finally his depression overcomes him. As André plays Oedipus, the Playwright not only prompts him but also points out similarities between André and the character he is playing:

PLAYWRIGHT. This is where the play really starts to get scary. You know what little Jennifer — your Antigone — said to me this afternoon? 'Why doesn't he stop and listen to the prophet and his wife. That way we could have a happy ending tonight.'

ANDRÉ. [with an exultant, almost brutal laugh.] Stop and listen? He can't! He is Oedipus!

PLAYWRIGHT. And so are you.

ANDRÉ. What do you mean?

PLAYWRIGHT. Just what you said earlier. You are like him in so many ways.

ANDRÉ. Those being ... my temper?

PLAYWRIGHT. That's one for sure. We're all terrified of you.

ANDRÉ. But what else? [The young playwright is reluctant to say more.] Come on! Speak up boy.

PLAYWRIGHT. There! The way you said that.

ANDRÉ. I see. Arrogance.

PLAYWRIGHT. You could call it that. (16)

André, like Oedipus, is majestic in defeat. Like Sophocles' play, this play again distills the original myth to discover its psychological clarity. This play is a paean to theatre itself, meant to thrill (perhaps even educate) audiences. Theatre is a way of life for André and a highly preferable alternative to what he sees as the conventional 
life that the Playwright chose by deciding to have a family. Theatre is the home of choice for André:

The stage is my real home. When I am up there, as cursed and reckless Oedipus, or neurotic Hamlet, or lovesick Hassan or any of the other emotional cripples I've played in my time, I know who I am, what I am, and why I am what I am. (23)

Theatre is an existential affirmation for André, just as writing is for the Playwright (whose writing certainly is centered in the theatre). This play celebrates both Huguenet's exit, and Fugard's entrance.

The plays discussed up to now are overtly classically influenced, but there are less overt ones. I often use Fugard's plays in my graduate course, which focuses on classical drama and its modern versions. This year the modern versions were all by Fugard: 'Heroism, Men and Women, and Colonialism: Ancient Drama and Plays by Athol Fugard'. Parallels were drawn between Aeschylus' Seven Against Thebes (ca. 467 BC) and Fugard's Blood Knot (1961); Seneca's Thyestes (ca. 50 AD) and NoGood Friday (1950); Sophocles’ Electra (ca. 413 BC), Euripides' Orestes (408 BC) and Fugard's Orestes (1971); Sophocles' Ajax (ca. 442 BC) and Fugard's My Children! My Africa! (1989); Sophocles' Antigone (ca. 442 BC) and Fugard's The Island (1973) and Road to Mecca (1984); Sophocles' Oedipus at Colonus (401 BC, posthumous) and Exits and Entrances (2004); Euripides' Phoenician Women (409 BC) and 'Master Harold'... and the boys (1982); Euripides' Medea (431 BC) and Fugard's Boesman and Lena (1969); Euripides’ Hippolytus (428 BC) and Fugard's Dimetos (1975); Euripides' Bacchae (405 BC, posthumous) and Fugard's Statements after an Arrest under the Immorality Act (1972); and Aristophanes' Frogs (405 BC) and Fugard's A Place with the Pigs (1987), one of his rare comedies.

There are obvious ways that the Classics can be used to interpret Fugard's work, for instance, by pointing out that there is a reverse Oedipal situation in Hello and Goodbye (1965): instead of a son killing a father, the father kills a son by fostering a dependence on him that never allows his son to be anything other than his shadow, even after he dies.

Fugard's most recent classical production is a short story that continues the story of Jason and Medea. It is moving and compelling, showing simple compassion for humanity. It shows Medea as unforgiving, still consumed by her hatred. This takes place after Jason is old, and scavenging for his food. He is successful in his begging when things go well, but every local disaster is blamed on him: he becomes the scapegoat, and food is refused.

He lives next to the rotting hulk of the Argo. He listens idly to the voice from the talking wood that the goddess placed there to help him on his voyage. For a long time it had been incoherent, but now it rehearses his story with Medea, and grows silent for the last time.

His ghostly sons begin to appear to him, ageless and dancing on the beach. He keeps quiet in admiration and wonder, but finally approaches them and they dance together in bacchic celebration of what is. Medea senses what is happening, and returns to what is her greatest failure, her relationship with Jason. She sees this wreck 
of a man as they stare at each other in mutual hatred. He spreads out his arms to shield something (it seems she cannot see the boys), and one of the timbers from the Argo falls on his head and he dies "struggling like an upturned beetle, arms and legs flailing the air and then stops suddenly. It was all over".

This is a beautifully sensitive reconstruction of Jason's end. Medea's desire for vengeance still consumes her, but Jason has regained the joy of his sons in this everlasting dance of Shiva.

Fugard's own dance with the Classics is far from over. He, like all of us, is influenced by a tradition that will never die as long as the world has eyes to see, and ears to hear.

\section{BIBLIOGRAPHY}

Butler, G 1990. Demea. Cape Town \& Johannesburg: David Philip.

Camus, A 1996. Notebooks 1935-1942. (Philip Thody Trans.) New York: Marlowe.

Fugard, A 1977. Dimetos, and Two Early Plays. Oxford/London/Melbourne: Oxford University Press.

Fugard, A 1984. Notebooks: 1960-1977. New York: Theatre Communications Group. Fugard, A 1990. My Children! My Africa! and Selected Shorter Plays. (Stephen Gray ed). Johannesburg, South Africa: Witwatersrand University Press.

Fugard, A 1993. The Township Plays. (ed. D Walder) Oxford: Oxford University Press.

Fugard, A 2002. Sorrows and Rejoicings. New York: Theatre Communications Group.

Fugard, A 2005. Exits and Entrances. Claremont, South Africa: David Philip.

Kitto, H D F 1991. The Greeks (1951, rpt). London: Penguin Books.

Laing, R D 1960. The Divided Self: A Study of Sanity and Madness. London: Tavistock.

Laing, R D 1964. Sanity, Madness and the Family: Families of Schizophrenics. London: Tavistock.

Maclennan, D The Palimpsest: Some Observations on Fugard's Plays. In Fugard, The Township Plays. (ed. D Walder) 217-23, Oxford: Oxford University Press.

Mandela, N 1995 (1994; rpt). Long Walk to Freedom. Boston, New York, London: Little, Brown and Co.

McDonald, M 1999a. Ancient Sun, Modern Light: Sole Antico, Luce, Moderna. (Francesca Albini, Trans.). Kleos. Bari: Levante.

McDonald, M 1999b. Mapping Dionysus in New Global Spaces: Multiculturalism and Ancient Greek Tragedy. In Patsalidis, S \& Sakellaridou, E (eds), (Dis)Placing Classical Greek Theatre. Thessaloniki: University Studio Press.

McDonald, M 2000. Black Dionysus: Greek Tragedy from Africa. In Theatre: Ancient and Modern, The January Conference, 95-108. Milton Keynes: Open University. 
McDonald, M and Walton, J M (eds) 2002. Amid Our Troubles: Irish Versions of Greek Tragedy. London: Methuen.

McDonald, M 2004. (Trans.) Sophocles'Antigone. London: Nick Hern.

Roscher W H 2000. Hidden Mutualities: Faustian Themes in the Postcolonial. Warwick: Unpublished thesis.

Smit, B 1974. Bacchus in die Boland. Johannesburg: Perskor.

Soyinka, W 2000. The Bacchae of Euripides: A Communion Rite. New York:W W Norton \& Co. Inc.

Vandenbroucke, R 1985. Truths the hand can touch : the theatre of Athol Fugard. New York: Theatre Communications Group.

Walder, D 1993. Crossing Boundaries: The Genesis of the Township Plays. In Twentieth-Century Literature. Athol Fugard Issue 39.4, 409-22. Winter 1993.

Wetmore, Kevin J Jr 2002. The Athenian Sun in an African Sky: Modern African Adaptations of Classical Greek Tragedy. Jefferson, North Carolina and London: McFarland \& Co.

Whitaker, R 1981. Dimoetes to Dimetos: The Evolution of a Myth. English Studies in Africa 24.1: 45-59. 